\title{
The Challenge of Introducing New Public Management to Kosovo's Healthcare Sector
}

\author{
Robert Mubarremi* \\ UDK $\quad 369.06(497.115)$ \\ 35.07: 614(497.115) \\ Review scientific paper / pregledni znanstveni rad \\ Received / primljeno: 11.3.2016. \\ Accepted / prihvaćeno: 15.3.2017.
}

The paper outlines the current healthcare sector reform process in Kosovo and the challenges to its implementation. The reform attempts to introduce modern public management principles into Kosovo's healthcare sector, including a purchaser-provider split, performance incentives, and performance-based contracting, as well as a reorganisation of healthcare service delivery with a view to improving effectiveness and efficiency. This is the first major reform of the healthcare sector since Kosovo declared its independence in 2008. A key challenge lies in the limited capacities of the Kosovo Government to implement such an ambitious reform. This is also an attempt to introduce modern public management principles into a public administration which is dominated by traditional public administration principles. Thus the lack of implementation capacities and contradictory public administration principles are the most important factors that may endanger the successful implementation of the reform.

* Robert Muharremi, PhD, Assistant Professor, Rochester Institute of Technology in Prishtina, Kosovo (docent Rochester Instituta za tehnologiju, Priština, Kosovo, e-mail: robert.muharremi@gmail.com) 
Keywords: healthcare reform, public management, public administration, purchaser-provider split, performance-based contracting, Kosovo

\section{Introduction}

This paper presents and discusses certain key aspects of the reform of Kosovo's health sector, which was initiated in 2009 and is still in progress. In the paper, health sector reform is understood as the sustained and purposive change to improve the efficiency, equity, and effectiveness of the health sector, with the goal of improving health status, obtaining greater equity, and obtaining greater cost-effectiveness for the services provided (Percival \& Sondrop, 2010, p. 1). The very purpose of the latest of reforms in Kosovo's health sector is to move away from the traditional public administration model and to introduce public management principles to improve cost-effectiveness and healthcare quality. The traditional model of public administration is characterised by a hierarchical bureaucracy, staffed by professional and politically neutral civil servants who execute policies developed at the political level, irrespective of which political party is in power (Hughes, 2012, p. 43-44). Public management, as opposed to the traditional public administration model, is seen as a different approach to the delivery of public services because (1) it focuses on outputs and outcomes rather than on inputs and processes, (2) public service performance is measured on the basis of performance indicators and standards, (3) public services are delivered on the basis on contractual and contract-like arrangements, (4) market-like mechanisms (such as privatisation of public services, outsourcing, public-private partnerships, competition, and creation of artificial markets through rationing and licensing) are introduced into the public service in order to improve its effectiveness and efficiency (Hughes, 2012, p. 88).

Kosovo's health sector reform must be analysed in view of the historical background that led to the re-establishment of the health sector following the armed conflict in 1998-99, NATO's military intervention, and the establishment of a United Nations (UN) interim administration in Kosovo in 1999. Although the UN re-established Kosovo's healthcare system, subsequent efforts to reform the system and to improve its performance failed. The Kosovo Government has initiated a new and ambitious healthcare reform building on the existing healthcare system, which was initially 
established by the UN. However, this reform faces serious challenges. Most importantly, it is an effort to introduce public management principles into the healthcare sector, while the overall administrative system follows traditional administration principles. While the policy design of the reform is sound, the implementation is the weak part of the reform process and likely to lead to another reform failure.

The purpose of the paper is to show that introducing complex new public management mechanisms such as the purchaser-provider split and performance-based contracting into the health sector, while the overall administrative system is still based on the principles of traditional public administration, coupled with weak management and implementation capacities, might be counterproductive for the improvement of efficiency, effectiveness, and equity in the healthcare sector.

\section{Development of Kosovo's Health Sector}

With a population of around 1.8 million, Kosovo has a GDP per capita of $2,935 €$ and can thus be categorised as a lower middle-income country. Around $50 \%$ of the population is under 25 years of age, which means that Kosovo has one of the youngest populations in Europe. However, the youth unemployment rate is officially at $30.2 \%$, while unofficial accounts estimate it to be around 55\%. The total unemployment rate is at $35 \%$. Thirty-five per cent of the population lives below the poverty line of $1.42 € /$ day, while $12.1 \%$ lives in extreme poverty with less than $0.92 € /$ day (Muzik \& Uka, 2013, p. 1). Life expectancy is at around 69 years, which is among the lowest in Europe, and government spending on health stands at $6.6 \%$ of GDP, which is also one of the lowest figures in Europe.

Before it declared independence in 2008, Kosovo was administered by the UN, beginning in 1999. The UN Interim Administration Mission was established by the UN, following a military intervention led by NATO against Serbia in response to massive human rights violations and the forceful expulsion of a large portion of Kosovo's civilian population. Before the intervention Kosovo was an autonomous province of the Socialist Federal Republic of Yugoslavia, which disintegrated in 1992, and subsequently it remained part of the Federal Republic of Yugoslavia, which included only Serbia and Montenegro. Its socialist past was reflected in Kosovo's health system, which was the same for the whole of Yugoslavia and was based on decentralised decision-making and specialisation 
of healthcare services. Polyclinics in major towns and municipalities were the first points of contact for patients and included different specialised healthcare services. The central government was both the purchaser and provider of healthcare services, while decision-making was decentralised to hospitals and healthcare centres (Percival \& Sondrop, 2010, p. 3).

Following the establishment of the UN administration in 1999, one of the first challenges for the international administration was to re-establish the healthcare system. Most of the healthcare centres had been damaged during the conflict or had been left without equipment and supplies. Most of the Serb medical personnel had left Kosovo, while the Albanian medical personnel were ill-prepared for the tasks due to a decade of exclusion from meaningful participation in the public health sector and a severe shortage of qualified doctors (Percival \& Sondrop, 2010, p. 5). The quality of the public healthcare system was compromised by the following factors: (1) shortages of healthcare personnel in rural areas, (2) lack of a functioning referral system, (3) duplication and inefficiency of healthcare services due to lack of cooperation and coordination between separate clinics and departments within the same hospital, and (4) high costs of access to healthcare services. Although healthcare services were officially free of charge, as they were funded by the government, patients incurred costs due to corruption and the need for private purchase of medication and basic material to be used by the doctors for medical treatment (Percival \& Sondrop, 2010, p. 5).

In 2000 the UN established the Administrative Department of Health and Social Welfare, which was responsible for the overall management of matters relating to health and social welfare in Kosovo (UNMIK Regulation No. 2000/10, Section 1.2). All administrative departments that were established by the UN operated under the overall legislative and executive authority of the UN Special Representative of the Secretary-General (UNMIK Regulation No. 2000/1, Section 1a) and were thus directly attributable to the UN. In 2001 the administrative department was transformed into the Ministry of Health, Environment and Spatial Planning (UNMIK Regulation No. 2001/19, Annex VI), while in 2002 a separate Ministry of Health was established (UNMIK Regulation No. 2002/5, Annex VI). The Ministry functioned under the Constitutional Framework for Provisional Self-Government in Kosovo, under which certain responsibilities were transferred to the Kosovo Provisional Institutions of Self-Government under the overall authority of the UN. 
A first step towards the reform of the healthcare sector was the introduction in 2000 of a patient co-payment system to supplement budget financing (Percival \& Sondrop, 2010, p. 5). Despite this, the financing of the healthcare system remained dependent on financial support from international donor organisations, amounting to around 80 million $€$ just between 1999 and 2002 (Percival \& Sondrop, 2010, p. 6). In view of this situation, the UN Interim Administration undertook the first major attempt to reform the healthcare system following the end of the conflict. A comprehensive legal framework was adopted to regulate the health sector, including a Law on Health, a Law on Private Practices in Health, and a Law on the Health Inspectorate. The objective of the reform was to strengthen primary healthcare services through the introduction of a family-medicine structure and to permit specialist treatment at secondary and tertiary level on a referral basis only, except in cases of emergency (Percival \& Sondrop, 2010, p. 7). The secondary level would consist of five hospitals and the tertiary level would be composed of the University Clinic in Prishtina. A further objective of the reform was to improve efficiency in hospitals through a reduction of the number of beds and the introduction of performance contracts and service agreements (Percival \& Sondrop, 2010, p. 7). The third component of the reform was the establishment of the Health Care Commissioning Agency within the Ministry of Health, as the predecessor of a health insurance fund to be established in future. The primary task of the Health Care Commissioning Agency was to create the basis for a split between purchaser and provider functions through performance-based contracts with municipalities for primary healthcare services, and with hospitals and the University Clinic in Prishtina for secondary and tertiary healthcare services (Percival \& Sondrop, 2010, p. 9). Furthermore, private clinics were permitted to operate subject to licensing and oversight by the Ministry of Health. A Health Inspectorate was established within the Ministry of Health to supervise the implementation by healthcare institutions of ethical and professional standards set by the Ministry of Health.

However, this reform enjoyed limited success for the following reasons (Percival \& Sondrop, 2010, p. 8-10):

1. The referral system failed due to "perverse" incentives resulting from the structure of the healthcare system. Low salaries in the public healthcare sector incentivised many family doctors to either leave the public healthcare sector entirely or to set up their own private clinics, where they would continue to work after their regular working hours. Referrals were very often made on the basis of "old practices", i.e., au- 
tomatic referrals without giving priority to treatment at primary level, or referrals to private clinics, where the same healthcare services were provided but at a much higher cost for patients.

2. The secondary and tertiary healthcare levels were underfunded, as the expectation was that the referral system would function and keep most of the medical treatment at primary healthcare level. This led to a deterioration of the quality of healthcare services at the secondary and tertiary levels.

3. The introduction of co-payments, the need for additional out-ofpocket payments, coupled with increased payment for private healthcare services due to referrals to private clinics, and other payments connected with corruption resulted in increased costs and barriers to access to healthcare services.

4. An inadequate health information system, coupled with lack of adequate management and accounting capacities across the sector, frustrated attempts to establish the foundations for a future split between purchaser and provider functions.

5. Immediately after its establishment, the Ministry of Health was confronted with charges of corruption and politicisation of appointments to civil service positions. This was aggravated by a lack of cooperation with international donors and local stakeholders, which hindered the implementation of the health sector reform. On top of that, the Ministry's professional capacities were limited because the civil service was recently put in place and lacked the necessary experience, and because positions were frequently filled based on political preferences rather than professional qualifications. The Ministry thus failed to exercise the stewardship function which was necessary to move the reform process forward.

A new reform was attempted in 2009. This time, the key difference was that the reform had local ownership as it was driven by the Ministry of Health and not by the UN. This was because in 2008 Kosovo had declared independence and the UN had since then ceased to exercise administrative functions in Kosovo.

\section{The New Health Sector Reform}

In 2009 the government adopted a new Health Sector Strategy which set three strategic objectives for the reorganisation of the health sector: (1) 
the improvement of the management of existing resources and quality of services, (2) a reorganisation and completion of the existing infrastructure of the healthcare system and the procurement of medical equipment in accordance with European standards, and (3) the development of a sustainable funding system for the health sector (Health Sector Strategy, 2009).

Based on these general objectives, the health reform was based on the following principles:

1. Introduction of a purchaser-provider split with an autonomous purchaser who will be responsible for purchasing health services from public and private health facilities.

2. Provider payment reforms which will introduce performance incentives to increase efficiency and improve quality, accompanied by corresponding changes in governance and accountability arrangements to give providers the autonomy to respond to performance incentives. Both hospitals and primary care facilities will ultimately be paid based on outputs adjusted for quality.

3. Introduction of mandatory health insurance to be funded through a combination of general tax revenues and citizen premiums (Health Sector Strategy, 2009).

The key elements of this reform were: (1) the introduction of a mandatory health insurance system, including the establishment of a Health Insurance Fund, (2) a redesign of the functions of the Ministry of Health, (3) the establishment of chambers of healthcare professionals to act as regulators of the medical profession, and (4) a redesign of the organisational structure of healthcare institutions, including the establishment of Kosovo Hospital and University Clinical Services as providers of healthcare services (Health Sector Strategy, 2009). In line with this, the Assembly of Kosovo adopted a new Law on Health in 2012, thereby formally endorsing the comprehensive reform of Kosovo's health sector. In addition, a new Law on Health Insurance and a Law on Chambers of Healthcare Professionals were adopted.

The reform process is confirmed by the new Health Sector Strategy 20152020, which is pending approval by the government. The fundamental pillars of the reform continue to be (1) the change of the health financing system from the existing centralised budget model into a combined financing model by both the budget and public and private health insurance systems, and (2) the decentralisation of the management of health institutions and professional resources from the political level to health 
institutions and health professionals themselves. The main purpose of the reform would be to make the Health Insurance Fund functional and to establish a definitive separation between the purchasers and providers of healthcare services. The Ministry of Health would have to be reorganised to strengthen its policy-making, regulatory, evaluation, and monitoring functions (Draft Health Sector Strategy, 2015)

However, as soon as the reform had begun, it was immediately resisted by certain interest groups, most notably by the medical profession, which was also strongly represented in the Kosovo Parliament. One of the critical provisions of the new Law on Health was the prohibition of health professionals who are employed in the public sector on a full-time or part-time basis to work in private healthcare institutions. It also included the prohibition of referring patients from a secondary or tertiary public healthcare institution to a private healthcare institution, unless justified for medical reasons (Constitutional Court 2013, p. 7). The purpose of this provision was to combat the illicit practice of referrals to private healthcare institutions, which was considered to constitute a conflict of interest (Constitutional Court 2013, p. 25) and a major source of corruption and malpractice in the public healthcare sector, given that many healthcare professionals who worked in public healthcare institutions also had their own private healthcare institutions. This practice was one of the main reasons why previous reform efforts had failed. This provision was challenged by several parliamentarians, led by a senior politician of the ruling political party who also happened to be a healthcare professional with a private healthcare institution. The challenge was made because the provision in question would violate the constitutionally guaranteed right to work (Constitutional Court 2013, p.2). The Constitutional Court ruled that such a restriction would be an unjustified interference with the right to work. The Constitutional Court reasoned that the Ministry of Health had not demonstrated how such a prohibition would contribute to securing comprehensive and quality healthcare in the public sector (Constitutional Court 2013, p. 28), and other less restrictive measures had not been assessed at all (Constitutional Court 2013, p. 30). Consequently, the Constitutional Court declared the provision to be unconstitutional and the Law on Health entered into force without this provision. Thus one of the cornerstones of the reform, i.e., the intention to combat illicit referrals from public to private healthcare institutions, which were a source of corruption and increased costs for patients, was destroyed even before the reform could kick off. 


\section{Health Sector Organisation}

The new reform organised the health sector around the Ministry of Health and the chambers of healthcare professionals as regulators; public and private healthcare institutions, including Kosovo Hospital and University Clinical Services (Kosovo Clinical Services, KCS), as providers of healthcare services; and the Health Financing Agency, to be succeeded by the Health Insurance Fund, as the purchaser of healthcare services (Draft Health Sector Strategy, 2015).

\subsection{Healthcare Regulators}

The Ministry of Health and the chambers of health professionals exercise regulatory and oversight functions over the health sector. The Ministry's primary role is to develop and implement health sector policies and laws, and to develop standards and regulations for the health sector. In addition, it has "stewardship and regulatory" functions, including the development of standards, development of healthcare infrastructure, human resources planning, and overall supervisory functions. The Ministry is supported by the Health Inspectorate and a Pharmaceutical Inspectorate as administrative bodies within the Ministry which exercise supervisory and monitoring functions.

The chambers of health professionals are professional organisations established by the Kosovo Assembly. They include chambers of doctors, dentists, pharmacists, physiotherapists, nurses, midwives, and other healthcare professionals. The chambers exercise certain public functions, such as the approval of the code of professional ethics for healthcare professionals, licensing of healthcare professionals, professional supervision, verification, and organisation of professional examinations. They are financed by the budget of the Republic of Kosovo for a three-year transitional period, after which they will be self-financed by means of membership fees, charges for licensing, and other fees and charges for services delivered to healthcare professionals.

\subsection{Healthcare Providers}

Healthcare services are provided by public, private, or joint public-private healthcare institutions. These are divided into primary, secondary, and tertiary healthcare institutions. While primary healthcare institutions remain under the administrative responsibility of the municipalities, sec- 
ondary and tertiary healthcare institutions are merged into KCS. Professional supervision of healthcare institutions is provided by chambers of healthcare professionals, while compliance with laws and standards is supervised by the Ministry through its inspectorates.

Primary healthcare services are provided by family health centres at the municipal level. Secondary healthcare institutions include general and special hospitals, specialist polyclinics, specialist offices, dentist offices, mental health centres, blood transfusion centres, and other medical centres. Tertiary healthcare institutions consist of the University Clinical Centre, University Dentistry Clinical Centre, National Institute of Public Health, and other national medical centres.

A novelty among healthcare institutions is KCS. It is designed as a unitary health institution composed of all the secondary and tertiary healthcare institutions. The secondary and tertiary healthcare institutions, which were integrated into and are now part of KCS, have the status of autonomous units within KCS, while legal personality is accorded to KCS only. Although at the initial stage of the reform only secondary and tertiary level healthcare institutions will be part of KCS, the Ministry of Health envisages the integration of primary healthcare institutions and private healthcare institutions into KCS at a later stage.

KCS is responsible for the provision of quality healthcare services based on performance, efficiency, and effectiveness. It is also mandated to coordinate specialised healthcare services and to ensure a high level of transfer and sharing of professional knowledge and experience between its constituent healthcare institutions. KCS is directed by a managing board comprised of seven members, who are appointed by the government upon the proposal of the minister of health. A representative of the Ministry is a member of the managing board. The managing board is accountable to the government through the minister of health. A general director, appointed by the managing board, manages the operational affairs of KCS and is responsible for its professional and financial performance.

The general idea behind the reform on the side of the provider is to introduce competition between healthcare institutions through contracts between them and the Health Financing Agency, and later the Health Insurance Fund. It is expected that with a fixed price for basic healthcare services, quality and the introduction of more efficient treatment methods will be the only parameters whereby the hospitals will be able to attract patients. The expectation is that this will introduce incentives to improve the quality of healthcare services. 
The expectation is also that KCS will strengthen the capacity for management, planning, and administration of the healthcare institutions which are part of it, and will thereby contribute to improving the management efficiency of healthcare institutions as providers of healthcare services. The functions currently exercised by the Ministry of Health with regard to supporting the operational aspects of healthcare institutions will be exercised by KCS. The intention is to establish clearer lines of responsibility and accountability, and to have a better separation between policy-making at Ministry level and operations at the level of KCS.

With the management of hospitals handed over to KCS, the Ministry will be able to focus more on its core tasks of policy-making, supporting political decision-making, defining strategic development, identifying incentives for the implementation of policies, strategies, norms, and standards, as well as drafting laws, but it will also be able to focus more on steering the reform process. This will require the establishment of a new organisational structure and professional capacities for policy-making, monitoring, and oversight.

\subsection{Healthcare Purchasers}

The purchasers of healthcare services are the Health Financing Agency and the Health Insurance Fund (once it has been established), as the future successor of the Health Financing Agency. The Health Insurance Fund negotiates and contracts basic healthcare services with healthcare institutions, which are licensed by the Ministry. The Health Insurance Fund is an independent legal entity established by law and managed by a steering board whose members are appointed by the government.

Until such time as the Health Insurance Fund is established, the Health Financing Agency, which is an executive agency of the Ministry of Health, will negotiate and enter into contracts with licensed healthcare institutions for the provision of basic healthcare services. The list of basic healthcare services will be approved by the government on an annual basis. Upon establishment of the Health Insurance Fund, the Health Financing Agency will gradually transfer its rights and responsibilities to the Fund.

\subsection{Healthcare Financing}

Healthcare financing is a mixed model of financing by both the budget and the health insurance system. In the initial stage, basic healthcare ser- 
vices will be funded by the budget and by co-payments made by patients, except for those patients who are exempt by law. Supplementary healthcare services will be funded by payments made by local or international health insurance companies.

With the establishment of mandatory health insurance, patients who pay premiums into the Health Insurance Fund, as well as those who are exempt from paying a premium, will have access to basic healthcare services approved by the government and provided by healthcare institutions which have entered into a contract with the Health Insurance Fund. The Health Insurance Fund will also receive transfers from the budget to cover basic healthcare services for persons exempt by law from paying premiums into the Health Insurance Fund. Non-insured patients and patients with private insurance will be entitled to emergency services free of charge, but will, for all other services, pay a price as defined by the price list for basic healthcare services.

The idea is that by the final stage of the reform, when the Health Insurance Fund is expected to have contracted private healthcare institutions as well, the price list for basic healthcare services will be applicable to all healthcare providers who will compete to attract patients. Supplementary healthcare services, i.e., those beyond the list of basic healthcare services approved by the government, will be provided at the market price calculated by each healthcare institution, or via private health insurance schemes.

\section{Problems and Issues}

There are several issues which require further attention because they are critical to the overall success of the reform.

\subsection{Purchaser-Provider Split}

Despite the government's explicit objective to introduce a separation between purchaser and provider in the health sector, there is concern about a possible confusion of the roles of purchaser and provider. The purchaser-provider split aims to introduce quasi-market incentives into the delivery of public services. Although there seems to be no generally accepted definition of the purchaser-provider split (Tynkkynen, Keskimaki \& Lehto, 2013, p. 221), it may be described in broad terms as an 
arrangement whereby the purchaser decides what and how much will be produced, while the provider delivers the agreed services (Ryan, Parker \& Brown, 2000, p. 221). This means that the purchaser of a service, who also pays for it, is organisationally separated from the service provider and that the relationship between purchaser and provider is regulated by contracts (Tynkkynen, Keskimaki \& Lehto, 2013, p. 221). The expectation is that such a separation between the purchaser and the provider and the contractual relationship between the two would create incentives that would lead to improvements in cost-effectiveness, greater efficiency, organisational flexibility, and, especially in the health sector, improved responsiveness of services to patient needs. The purchaser-provider split works on the assumption that the purchaser will be able to articulate the needs of the population and thereby determine what and how much of it should be produced. It is also assumed that a separate purchaser would have better awareness of the cost-effectiveness and quality of services, and thus allocate resources more efficiently (Tynkkynen, Keskimaki \& Lehto, 2013, p. 221). The provider would be distanced from policy-making and would deliver services based on the performance and output indicators defined in the contract with the purchaser (Ryan, Parker \& Brown, 2000, p. 221). A further benefit of the purchaser-provider split would be the ability of the purchaser to contract different providers and thus introduce competition between providers, which is expected to lead to improved efficiency and service quality (Tynkkynen, Keskimaki \& Lehto, 2013, p. 221).

Applying this concept to the health sector means that healthcare institutions such as hospitals are the providers of healthcare services. They would generate revenue by delivering healthcare services based on contracts with the purchaser, i.e., the Health Insurance Fund, instead of being funded by the government budget. Competition between different providers for contracts with the purchaser would require the providers to deliver more services at higher quality and lower cost, which would eventually lead to better value for money of the healthcare services they provide.

The purchaser-provider split adopted in Kosovo's health sector reform does not possess all the above features. The provisions in the Law on Health $^{1}$ and the Statute of KCS ${ }^{2}$ are contradictory and confusing in respect of the purchaser-provider separation. The general rule seems to be

\footnotetext{
${ }^{1}$ Law No. 04/L-125 on Health, Official Gazette 13/2013.

2 Statute of the Hospital and University Clinical Kosovo Clinical Service of Kosovo, adopted by the Government of Kosovo on 11.09.2013 (Decision no. 05/148).
} 
that the Health Financing Agency is required to negotiate and contract healthcare services with healthcare institutions, which implies cost-effectiveness competition between different healthcare institutions as providers. The details, however, are not entirely clear and allow for different legal interpretations.

On the one hand, KCS is required to enter into contractual relations with the Health Financing Agency. As KCS integrates all secondary and tertiary healthcare institutions as its organisational units, the price list proposed by KCS and approved by the Health Financing Agency, and any contract entered into between KCS and the Health Financing Agency will also be applicable to healthcare institutions which are components of KCS. This will eliminate competition between different healthcare institutions for contracts with the purchaser, which is a key feature of the purchaser-provider separation model. It is also unclear if, and to what extent, contractual relations between KCS and the Health Financing Agency will be based on competitive contract award procedures. In fact, KCS will have a monopoly over providing healthcare services funded by the budget for the secondary and tertiary healthcare levels, which will render any competitive contract award procedures obsolete.

On the other hand, the Health Financing Agency is mandated to also contract directly with healthcare institutions for the provision of basic and supplementary healthcare services. However, nowhere is it explicitly stated that such contracts should be awarded on a competitive basis. Instead, the Health Financing Agency is only required to set a performance stimulation scheme for health professionals and relevant professional services at all three levels of healthcare, based on objective and transparent criteria to meet the volume and quality indicators of healthcare services provided by the sub-legal act issued by the Ministry. This structure causes confusion and seems to be in contradiction to the above claim that the price list for healthcare services offered by KCS funded by the budget must be approved by the Health Financing Agency. It is therefore not clear when the Health Financing Agency should enter into a contract with KCS, and when with individual healthcare institutions.

A further element to be considered is the fact that KCS and its component healthcare institutions will continue to be funded by the budget. This may reduce incentives to be cost-effective, especially as the Ministry and the Government stand behind both KCS and the Health Financing Agency because the management of both entities is appointed by the government. This may also lead to the question of whether there is real separation between purchaser and provider, which will focus on improv- 
ing efficiency and be insulated from political considerations, and to what extent KCS and the Health Financing Agency will be immune from political interference.

\subsection{Kosovo Clinical Services}

The legal nature of Kosovo Clinical Services is not clear and may lead to confusion in regard to its relationship with its constituent healthcare institutions. On the one hand, KCS is defined by the Law on Health (Art. 3, paragraph 1.18) as a healthcare institution, which means that it is a provider of healthcare services. However, healthcare services are in fact provided by the healthcare institutions which are members of KCS. The functions assigned to KCS relate primarily to negotiation with the Health Financing Agency, management, analysis, planning, and quality control. The Statute of KCS (Art. 6) defines the healthcare institutions which are part of KCS as autonomous units that organise and manage their common and regular administrative and professional affairs in order to fulfil their duties and legal responsibilities, save for the functions vested in KCS. Healthcare institutions can also contract directly with the Health Financing Agency. These aspects indicate that KCS is a managerial "superstructure" for its member healthcare institutions, or an association of healthcare institutions, rather than a healthcare institution which provides healthcare services.

On the other hand, KCS receives payments from the public budget, while no such budget is granted to its member healthcare institutions. KCS may also negotiate directly with the Health Financing Agency. In relation to the healthcare institutions, KCS prepares proposals of internal acts of its member healthcare institutions for approval by the minister of health; it ensures that the organisational and functional units of KCS are well-managed; that their directors are focused on quality healthcare services and have ambitious and realistic financing plans; and it approves profits, fusions, divisions, and dissolutions of the organisational units of KCS. The picture presented by these functions and responsibilities indicates that KCS seems to be more than just a managerial superstructure of an association of healthcare institutions, but instead the nucleus of a future unified and integrated healthcare institution.

KCS can therefore at best be defined as a hybrid institution, which is at present a managerial superstructure entrusted with the management of its constituent healthcare institutions and which may develop in future into 
a unified healthcare institution. Its hybrid character may lead to legal and organisational ambiguity and thus contribute to difficulties with regard to the clear definition of contractual relations between the Health Financing Agency and the providers of healthcare services.

\subsection{Performance-Based Contracting}

The Ministry piloted the introduction of performance contracts with all public healthcare institutions in 2013. Based on this experience, it decided to introduce permanent performance contracting with all hospitals. The expectation is that all public health institutions will enter into performance contracts with the Health Financing Agency, to be superseded by the Health Insurance Fund, which also must build the basic capacity to monitor the implementation of the contract, to support decision-making with respect to performance payment, and to administer performance payment.

A proper performance-based contracting mechanism requires the introduction of performance-based management structures within KCS, healthcare institutions, and the Health Financing Agency. KCS and healthcare institutions must have the organisational and personnel capacity for establishing strategic performance objectives, measuring performance, collecting, analysing, reviewing, and reporting performance data, and using those data to drive performance improvement. This capacity is very limited at present. In addition, the implementation of performance-based contracting will require a fundamental restructuring of healthcare institutions not only in terms of structure and process, but also in terms of reframing the mindset of its managers and employees so as to become customer, results, and performance oriented. Performance-based contracting without equivalent performance-based management structures may not create the right incentives and may lead to a failure of this policy.

\subsection{Sequencing and Coordination of Reform}

The organisational building blocks of the reform, i.e., the Ministry of Health, professional chambers, KCS, the Health Financing Agency, and the Health Insurance Fund have attained different levels of policy attention and different levels of development. 
KCS is well-advanced in terms of establishing its management structure, but a comprehensive clarification of its role and relationship with its member healthcare institutions is still lacking. Neither KCS nor the healthcare institutions have started to establish performance-based management structures, although the implementation of performance-based contracts is already in progress. The Health Financing Agency is in a similar situation. The Ministry has divested itself of operational functions by transferring them to KCS, but it has not restructured itself to adjust to its new regulatory function. The professional chambers are not operational yet, as their functions are still being exercised by the Ministry.

The successful implementation of the reform will require a careful sequencing and synchronisation of reform steps, while ensuring the overall continuity of healthcare regulatory functions and services. It must be ensured that all the building blocks of the reform are managed and reformed in such a manner that they assume and exercise their new functions in a coordinated way.

This requires a comprehensive policy and a detailed implementation plan; however, both are missing. There is an impression that the implementation of the reform does not follow an established plan, but an incremental logic with the possibility of making modifications and adjustments along the way. Although the reform design and implementation process is concentrated in the Ministry of Health, there is no central unit or task force within the Ministry which would assist in steering and monitoring the reform process. Furthermore, stakeholder involvement is minimal, with the consequence that the healthcare profession and the public have limited information about the ongoing reform process and the expected outcomes.

The reform process is exposed to multiple risks that need to be managed to avoid another reform failure. The reform process may encounter resistance from healthcare institutions due to the introduction of performance-based management and a payment system with which they are not familiar and lack the necessary expertise. Lack of clarity about the relationship between the healthcare institutions and KCS may diminish support for the integration of the healthcare institutions into KCS. Overly complex and unclear management structures within KCS, coupled with a lack of professional leadership and a shortage of staff trained and experienced in the establishment and operation of contract and performance-based management structures may lead to a dysfunctional KCS.

Resistance may also come from certain parts of the civil service of the Ministry, due to the loss of control over and influence on the operational 
aspects of healthcare services, e.g. public procurement and human resources management, as these functions have been transferred to KCS. The Ministry may hesitate to focus exclusively on policy formulation and supervision and thus refrain from intervening the in operational aspects of KCS and the Health Financing Agency. A recent decision of the Ministry to relax licensing requirements for clinical psychologists may be indicative of the imminence of such a risk.

A further key challenge for the Ministry will be to restructure internally to be able to effectively exercise its regulatory functions and to steer the reform process. A specific issue in this context is the sequencing of activities to implement the purchaser-provider split and performance-based management, while establishing the organisational units of the health sector. The risk is that the Ministry may be moving forward with the establishment of the legal and institutional framework without devoting the necessary attention and resources to building the required human and structural capacity to implement performance-based management and the purchaser-provider split model. Public support for the reform could also diminish if improvements in healthcare services are not quickly visible.

The development and implementation of a sound stakeholder management system is a critical prerequisite for mitigating risks emanating from stakeholders. It is essential that expectations related to the outcomes of the reform are managed in a realistic manner. Ensuring transparency and the meaningful participation of all stakeholders in the reform process is of paramount importance in order to generate support and diminish resistance. The development and implementation of a properly structured and sequenced change management system is also critical to the success of the reform, especially in order to implement the envisaged performance-based management system and the purchaser-provider separation model.

\section{Conclusion}

This entire reform process may require Kosovo to deliver more than it is able to because of its weak administrative capacity. Regarding the health sector, the EU Progress Report for Kosovo in 2014 specifically highlighted that public health spending would remain among the lowest in the region and that this would hinder the implementation and enforcement of sector 
reforms and policies. The EU also noted that with respect to the overall performance of Kosovo's public sector the capacity in ministries to plan and budget remains limited (EC, 2014, p. 10). The EU also expressed the criticism that regarding public service and human resources management political interference in public administration would continue to persist, both at the central and local level, and that very limited progress has been made to further improve accountability and service delivery (EC, 2014, p. 11). The report noted that Kosovo has not addressed public financial management reforms systematically, as part of a comprehensive reform plan; that its medium-term expenditure framework, which covers the period 2015-2017, lacks a strategic approach; and that the annual budgeting process would still be based on the line-item approach (EC, 2014, p. 11). Most importantly, the implementation of public internal financial control would still be at an early stage, as the managerial accountability principle has not yet been embedded in the management culture (EC, 2014, p. 12).

The introduction of a complex public management system characterised by a purchaser-provider split and performance-based contracting in the health sector, while the overall administrative system is built on the principles of traditional public administration, coupled with weak management and implementation capacities, looks like a recipe for another reform failure. It is difficult to imagine how such a reform will work when the rest of the administrative system, including budgeting and human resources management, operates in a bureaucratic manner, following traditional public administration models. The risk is that this incongruence between a performance-oriented health sector and the rest of the public administration will lead to confusion and conflicts, and eventually result in reform fatigue. It may also expose the reform process to attacks from various interest groups, which see their vested interests threatened by the reform process and see exploiting these structural defects as a chance to undermine the reform. In the end, the success of the reform will depend on the determination of the Ministry of Health to continue with the reform process and to first reform itself to be able to competently steer the reform process.

The Ministry of Health must take the following seriously: reform means sustained and purposive change and it is a process which requires a significant period of time and resources. The Ministry of Health will also need to resist the temptation to fall back into the "old practices" of getting involved in operation matters which have been devolved to KCS, the Health Insurance Fund, and professional chambers. If the reform succeeds, i.e., if the purchaser-provider split and performance-based contracting indeed work out as expected, there is a good chance that the public management 
oriented reform of the health sector may have spillover effects on other areas of Kosovo's public sector, such as budgeting and civil service. If not, then bureaucratic administration will continue to be the standard for some time.

\section{References}

EC. (2014). EU progress report Kosovo. Retrieved from http://ec.europa.eu/enlargement/pdf/key_documents/2014/20141008-kosovo-progress-report_en.pdf

Government of the Republic of Kosovo/Ministry of Health (2009). Health sector strategy 2010-2014. Retrieved from http://mei-ks.net/repository/docs/ANNEX_10_-_Health_V.pdf

Government of the Republic of Kosovo/Ministry of Health (2015). Health sector strategy 2015-2020 (Unpublished draft strategy). Prishtina, Kosovo.

Hughes, O. (2012). Public management \& administration. London, United Kingdom: Palgrave Macmillan.

Muzik, R., \& Uka, A. (2013). Kosovo: Brief health system review. Retrieved from http://www.hpi.sk/en/2013/11/kosovo-brief-health-system-review/

Percival, V., \& Sondrop, E. (2010). A case study of health sector reform in Kosovo. Conflict and Health 4(7), 1-14.

Ryan, N., Parker, R., \& Brown, K. (2000). Purchaser-provider split in a traditional public service environment: Three case studies of managing change. Public Policy and Administration Journal 9(1), 206-221.

Tynkkynen, L., Keskimaki, I., \& Lehto, J. (2013). Purchaser-provider splits in health care: The case of Finland. Health Policy 111(3), 221-225. doi. http:// dx.doi.org/10.1016/j.healthpol.2013.05.012

\section{Legal sources}

Constitutional Court of the Republic of Kosovo (2013). Judgment in the Case No KO131/12, Prishtina, 15 April 2013.

Law No. 04/L-125 on Health, Official Gazette of the Republic of Kosovo 13/2013. Retrieved from http://gzk.rks-gov.net/ActDetail.aspx?ActID=8666

Statute of the Hospital and University Clinical Service of Kosovo, adopted by the Government of Kosovo on 11.09.2013 (decision no. 05/148). Retrieved from http://www.kryeministri-ks.net/repository/docs/Statuti_i_sherbimit_spitalor_dhe_klinik_universitar_i_Kosoves.pdf

UNMIK Regulation No. 2000/10 on the establishment of the administrative department of health and social welfare, UNMIK Official Gazette 2000.

UNMIK Regulation No. 2000/1 on the Kosovo joint interim administrative structure, UNMIK Official Gazette 2000. 
UNMIK Regulation No. 2001/19 on the executive branch of the provisional institutions of self-government in Kosovo, UNMIK Official Gazette 2001.

UNMIK Regulation No. 2001/9 on a constitutional framework for provisional self-government in Kosovo, UNMIK Official Gazette 2001.

UNMIK Regulation No. 2002/5 amending UNMIK Regulation No. 2001/19 on the executive branch of the provisional institutions of self-government in Kosovo, UNMIK Official Gazette 2002.

\section{THE CHALLENGE OF INTRODUCING NEW PUBLIC MANAGEMENT TO KOSOVO'S HEALTHCARE SECTOR}

\section{Summary}

The paper outlines the current bealthcare sector reform process in Kosovo and the challenges to its implementation. The reform attempts to introduce modern public management principles into Kosovo's bealthcare sector, including a purchaser-provider split, performance incentives, and performance-based contracting, as well as a reorganisation of healthcare service delivery with a view to improving effectiveness and efficiency. This is the first major reform of the bealthcare sector since Kosovo declared independence in 2008, and it intends to replace the bealthcare system established by the United Nations between 1999 and 2008. Kosovo's earlier healthcare system had been characterised by decentralised decision-making, but was re-established by the UN in the form of an emergency bealthcare system after the UN was deployed to administer Kosovo in 1999. The reform envisages separating bealthcare regulators from bealthcare providers and bealthcare purchasers. Kosovo Hospital and University Clinical Services is established as a new entity providing bealthcare services, and a new Health Insurance Fund will become the bealthcare purchaser. The Ministry of Health will be restricted to the functions of a regulator, divested of all administrative functions in favour of healthcare providers and purchasers. A major challenge lies in the limited capacities of the Kosovo Government to implement such an ambitious reform. This is also an attempt to introduce modern public management principles into a public administration which is dominated by traditional public administration principles. Lack of implementation capacities and contradictory public administration principles are the most important factors that may endanger the successful implementation of the reform.

Keywords: bealthcare reform, public management, public administration, purchaser-provider split, performance-based contracting, Kosovo 


\section{Muharremi, R. (2017). The Challenge of Introducing New Public Management ... \\ IZAZOV UVOĐENJA NOVOGA JAVNOG MENADŽMENTA U KOSOVSKI ZDRAVSTVENI SEKTOR}

\section{Sažetak}

U radu se opisuje reforma zdravstvenog sektora Kosova te izazovi s kojima se ona susreće. U sklopu reforme u kosovski se zdravstveni sektor nastoje uvesti načela modernog javnog menadžmenta, uključujući podjelu na pružatelja $i$ kupca javnib usluga te ugovaranje temeljeno na rezultatima. Također, nastoji se provesti reorganizacija pružanja zdravstvenib usluga s ciljem povećanja djelotvornosti i učinkovitosti. Radi se o prvoj opsežnoj reformi kosovskoga zdravstvenog sektora od proglašenja nezavisnosti 2008. te se njome nastoji zamijeniti sustav koji su Ujedinjeni narodi postavili u izvanrednim okolnostima 1999., a kojim je zamijenjen dotadašnji zdravstveni sustav koji se temeljio na decentraliziranom odlučivanju. Reformom se namjerava razdvojiti regulatore zdravstvenog sustava od pružatelja $i$ kupaca zdravstvenib usluga. Uvodi se unitarna ustanova nazvana Kosovske kliničke usluge kao novi pružatelj zdravstvenib usluga, dok novi Fond za zdravstveno osiguranje preuzima ulogu kupca zdravstvenib usluga. Funkcija Ministarstva zdravstva bit će isključivo regulacijska te će ono izgubiti sve upravljačke funkcije u korist pružatelja $i$ kupaca zdravstvenih usluga. $S$ obzirom na velike ambicije koje se ovom reformom žele ostvariti, velik izazov predstavljaju ograničeni provedbeni kapaciteti kosovske vlade. Reforma također predstavlja pokušaj uvođenja modernib načela javnog menadžmenta u javnu upravu kojom dominiraju tradicionalna načela. Upravo manjak provedbenih kapaciteta $i$ proturječna načela predstavljaju glavne faktore koji bi mogli ugroziti uspješnu provedbu reforme.

Ključne riječi: reforma zdravstva, javni menadžment, javna uprava, podjela na pružatelja $i$ kupca, ugovaranje temeljeno na rezultatima, Kosovo 